\title{
Should I Stay or Should I Go? Linking Career Decision-Making Self-Efficacy to Intention to Stay in the Hospitality Industry Based on Internship Experience
}

\author{
Chung-Jen Wang
}

Citation: Wang, C.-J. Should I Stay or Should I Go? Linking Career Decision-Making Self-Efficacy to Intention to Stay in the Hospitality Industry Based on Internship Experience. Sustainability 2021, 13, 10571. https://doi.org/10.3390/ su131910571

Academic Editor: Osman M. Karatepe

Received: 3 September 2021

Accepted: 21 September 2021

Published: 23 September 2021

Publisher's Note: MDPI stays neutral with regard to jurisdictional claims in published maps and institutional affiliations.

Copyright: (C) 2021 by the author. Licensee MDPI, Basel, Switzerland. This article is an open access article distributed under the terms and conditions of the Creative Commons Attribution (CC BY) license (https:/ / creativecommons.org/licenses/by/ $4.0 /)$.
Department of Hotel and Restaurant Management, National Pingtung University of Science and Technology, Pingtung 912301, Taiwan; wchungzen@gmail.com; Tel.: +886-8-770-3202

\begin{abstract}
Internships are increasingly being used in the hospitality industry, as these can provide students with opportunities to examine their abilities, interests, and career decisions in a workplace context, as well as help cultivate human resources within this sector. This study thus examines students' career decision-making self-efficacy with regard to internships. Based on social cognitive theory and career decision-making self-efficacy theory, we developed the research constructs with a focus group interview and a review of the existing literature, and then verified their content validity and scale reliability. Using 782 student data from the hospitality management departments, we found the direct influence of career decision-making self-efficacy in relation to internships on the intention to stay in the hospitality industry. Most important of all, we also found the mediating roles of internship satisfaction and career commitment in the relationship between decision-making selfefficacy and intention to stay in the hospitality industry, as well as the moderating roles of intrinsic motivation in the relationships among career decision-making self-efficacy, internship satisfaction, career commitment, and intention to stay in the hospitality industry. The theoretical and practical implications of these results in the context of hospitality will be discussed.
\end{abstract}

Keywords: hospitality; internship; sustainable growth; career decision-making self-efficacy; mediation; moderation

\section{Introduction}

Internships are gateways from the classroom to the real world, and provide inexperienced students with chances to examine their abilities, interests, and career decisions in a workplace context [1,2]. With regard to students in hospitality management departments, internships are not only essential for their university studies, but also a reliable way to gain their first jobs. A successful internship can encourage students to focus their careers plans on the hospitality industry [3-5]. In addition, self-efficacy refers to an individual's belief in their capabilities to mobilize the cognitive resources and motivation needed to achieve a certain action or carry out specific tasks [6-10]. On the basis of Bandura's [11] social cognitive theory, higher self-efficacy enhances motivation, cognition, and emotion in relation to the learning process. Although self-efficacy has been widely applied to different domains of career assessment, one of the key applications is in the concept of career decision-making self-efficacy [12]. Career decision-making self-efficacy refers to a person's degree of confidence about their capability to make career decisions successfully [13-16]. Furthermore, Betz et al. [12] proposed that career decision-making self-efficacy is composed of five competencies: accurate self-appraisal, goal selection, gathering occupational information, problem-solving, and making plans for the future. In other words, students in internships who have high career decision-making self-efficacy will make more effort regarding the decision process, persist in finding solutions for the problems they face, and engage more actively in career development efforts [17]. Most important of all, these qualities can help to increase their intention to remain in the hospitality industry after their 
internship has been completed. In addition, when students feel satisfied with internships due to factors such as promotion, payment, leadership, co-workers, and the job itself, they have a great propensity to pursue the same career and make more effort in doing so [18,19]. Similarly, career commitment refers to the commitment a person feels with regard to their work [20], and can also influence their intention to remain in the same industry. Though previous studies have investigated the single relationship between internship satisfaction, career commitment, career decision-making self-efficacy, and intention to stay in the hospitality industry [3,21-25], there is still a lack of an integrative perspective to discover the causal linkages among the aforementioned variables. Therefore, the first question that the research aims to answer is whether internship satisfaction and career commitment in the proposed model could mediate the relationship between students' career decision-making self-efficacy and their intention to stay in the hospitality industry, thus filling the research gap or missing pieces in the research of hospitality literature.

Second, intrinsic motivation refers to students' natural cognitive tendency toward mastery and a natural interest in a subject, rather than their efforts being due to external pressures or rewards. Intrinsic motivation is thus critical with regard to enjoyment, curiosity, and involvement at work [26-29]. In other words, students with high intrinsic motivation will make extra efforts to learn the knowledge or skills required at work, and then apply these techniques in novel ways [26,30]. Accordingly, when students are taking part in their internships, they can have more chances to understand and assess their own values with regard to intrinsic motivation. Moreover, they can not only experience their perceived self-efficacy, but also learn whether their intrinsic motivation will be promoted or maintained in the workplace. Prior studies have revealed that intrinsic motivation may raise the positive relationship between decision-making self-efficacy and career commitment, and strengthen the positive relationship between career commitment and intention to stay [31-33]; however, a deeper understanding of the status of the body of knowledge with empirical data in hospitality field is still needed. As a result, the second question that the research aims to answer is whether intrinsic motivation could moderate the positive relationships among students' career decision-making self-efficacy, internship satisfaction, career commitment, and their intention to stay in the hospitality industry, and whether such relationships are stronger when individuals have relatively high versus low intrinsic motivation. More specifically, this study aims to provide a clearer picture of the vital moderating roles of intrinsic motivation in the proposed integrated model for hospitality internship.

In this article, the following sections include a literature review and hypotheses development, followed by methodology, and findings of the empirical results. Finally, the article concludes with discussions regarding theoretical and practical implications, limitations, and suggestions future research, as well as conclusions of this study.

\section{Literature Review and Hypotheses Development}

\subsection{Hospitality Internship}

Internship refers to a student's work-related experiences before graduation, and these are often related to the academic programs they are taking [34]. Internships, when supported by career development plans, enable students to acquire real industry experience, improved learning opportunities, expanded social networks, and better chances of obtaining a job placement after graduation $[35,36]$. Scholars have reported the benefits of internships to students, and the three critical parties in this context are business owners, students, and higher education institutions [37-40]. Furthermore, in hospitality management programs, internships are the key indicators that are used to evaluate the quality of the education that an institution is providing [35]. Through successful internships, students can learn more about their future careers, and this can then promote their resolution to keep working in the hospitality industry [3]. Hospitality education should thus aim to strengthen the abilities of students with regard to future internships, and so help them to make better career decisions. Given that students from hospitality-related programs are the 
major source of manpower for the industry, successful learning and internship experiences at the university level are vital factors that influence students' perceptions, attitudes, and confidence with regard to their future career intentions in the hospitality industry.

\subsection{Social Cognitive Theory}

According to Bandura [11], social cognitive theory is a theory that focuses on the process of a person's learning from others, and the development of their personality. As people learn from others, personal, behavioral, and environmental factors will influence the development of learning. These three factors are dynamic and affect each other in a triadic, reciprocal, and deterministic manner. For instance, behavioral observations can influence a person's cognition, the living environment can decide a person's behaviors, and parents' ways of thinking have a great influence on the environment that their children grow up in. In addition, social cognitive theory also proposes that learning will happen more often in a place where there is a close identification between the role model and observer. In other words, when the observer believes they have the self-efficacy needed to act like the role model. Identification allows the connection between the role model and observer, and the latter thus obtains the imitated behavior. Accordingly, self-efficacy determines the degree of motivation, cognition, and emotion in the learning process.

Furthermore, Bandura $[6,41]$ suggested that different types of experience and other factors decide the growth of one's self-efficacy: vicarious experience (also called modeling), mastery experience (also known as enactive mastery), physiological factors (also called one's physiological and affective state), and social persuasions (also known as verbal persuasion). The most effective way to develop self-efficacy is through the use of mastery experience, in which more challenging tasks can be introduced after simpler tasks have been completed. Observation of similar people's success is also a source of self-efficacy, because it raises individuals' beliefs that they also have the abilities needed to succeed. In addition, a person can be persuaded that they have these abilities for success if important others provide encouragement that they can achieve their goals. Finally, physiological factors, such as stress levels, emotional reactions, and physical reactions, can influence self-efficacy, and a person cannot have strong self-efficacy if they feel nervous about doing their assigned tasks. Bandura thus defined self-efficacy as an individual's belief in their own abilities to mobilize the cognitive resources and motivation needed to take action to carry out specific tasks [6,7].

Although self-efficacy has been widely applied to various domains of career assessment (e.g., education, management, work tasks, career attitude, and behavior), one of its most important applications is in the concept of career decision-making self-efficacy [12]. Career decision-making self-efficacy is a person's degree of confidence in their personal abilities to make career decisions successfully [13-15]. Betz et al. [12] thus theorized that career decision-making self-efficacy is composed of five competencies: accurate self-appraisal, goal selection, gathering occupational information, problem-solving, and making plans for the future. Accurate self-appraisal, or self-appraisal, refers to the capability to accurately appraise one's own values and interests with regard to one's career decisions. Goal selection refers to the capability to match one's own attributes with the demands of a specific career, and thus identify which major to pursue as a student. Gathering occupational information, or occupational information, refers to the capability to discover sources of information with regard to majors and occupations, and have discussions with people employed in jobs of interest. Problem-solving refers to one's capacity to figure out solutions or coping strategies when meeting unexpected problems. Finally, making plans for the future, or planning, refers to the capability to implement career choices, including making resumes, job searches, and interview preparation [15,42-44].

\subsection{Career Decision Self-Efficacy and Intention to Stay in the Hospitality Industry}

Since self-efficacy influences employees' work-related initiation, attraction, and sustenance [7,45-47], Peterson [48] suggested that the concept of career decision-making 
self-efficacy could be used to improve a person's career development and increase their willingness to stay within their current organizations. Adachi [49] also revealed that individuals with high career decision-making self-efficacy take more interest in career activities and achieve more favorable outcomes with the support of greater vocational motivation. Similarly, Jantzer, Stalides, and Rottinghaus [50] proposed that career decision-making self-efficacy could contribute to vocational identities, as well as further intention to stay within the focal industry, based on a sample of 820 students. In other words, students with high career decision-making self-efficacy make efforts with regard to the decision process, persist in finding solutions for difficulties they face, and engage in their career decisions more actively, thus making their ultimate success more likely [17]. Most important of all, such factors all help to enhance the intention to remain working in the present industry. As a number of prior studies have shown evidence of the correlation between career decision-making self-efficacy and intention to stay in the industry, we propose the following hypothesis:

Hypothesis 1. Career decision-making self-efficacy is positively related to intention to stay in the hospitality industry.

\subsection{The Mediating Roles of Internship Satisfaction and Career Commitment}

In the context of the current study, satisfaction is an individual's affective attachment with regard to their work in its entirety or in relation to a specific particular facet [51]. When a person is more satisfied with work-related factors such as promotion, payment, leadership, co-workers, and the job itself, they are more likely to remain in the same career and make more effort while doing so [18,19]. Moreover, high career decision-making selfefficacy is typically reflected in a person's belief that they can competently complete their work tasks, and such people tend to anticipate positive outcomes, thus leading to greater satisfaction [52-54]. There is some evidence that enhancing students' career self-efficacy can also raise their internship satisfaction. For instance, Dahling and Thompson [55] reported that career decision-making self-efficacy can improve certain vocational outcomes, such as work satisfaction and perceived career fit. Similarly, Wright and Perrone [56] found that social and career decision-making self-efficacy can increase life and career satisfaction, based on a survey of college students. Jadidian and Duffy [21] also reported that career decision-making self-efficacy has positive influences on academic and work satisfaction, according to a sample of 447 undergraduate students. Moreover, improved student internship satisfaction is associated with better career identification, more career opportunities, and greater intention to stay in the focal industry [52]. For example, Chen and Shen [3] proposed that internship satisfaction and student industry involvement can affect the willingness to seek a career in the same industry after their graduation. Chiang, Back, and Canter [57] also reported that satisfaction with work can improve an individual's intention to stay in the industry, based on a sample of hotel employees in USA. In addition, Fuller, Hester, Dickson, Allison, and Birdseye [22] showed that satisfaction at work has a positive relationship with regard to outcomes such as intention to stay, according to two meta-analyses. Therefore, if students have high career decision-making self-efficacy then this will lead to more satisfaction with regard to their internship, thus enhancing their intention to stay in the hospitality industry. Accordingly, the second hypothesis is as follows:

Hypothesis 2. Internship satisfaction mediates the relationship between career decision-making self-efficacy and intention to stay in the hospitality industry.

An individual's attitude with regard to their career is one of the most important issues with regard to their level of career commitment [20,58]. Career commitment is a measure of the extent to which an individual is devoted to their work [20]. Moreover, the degrees to which a person identifies with and feels confident toward their works 
have positive effects on their career commitment [59]. In other words, individuals' career decision-making self-efficacy plays a crucial role in the selection of work settings and can be regarded an antecedent of career commitment. For example, Chung [23] found that students' career decision-making self-efficacy can influence their career commitment, using a sample of 165 undergraduates. Jin et al. [60] reported that career decision-making self-efficacy can strengthen career commitment and lessen the tendency to quit one's job based on a sample of 785 Chinese graduate students. Chemers, Zurbriggen, Syed, Goza, and Bearman [61] also showed that an individual's efficacy and degree to which they identify with their career can predict the level of career commitment, using a student sample of 327 undergraduate and 338 graduate students. In addition, intention to stay in an industry can be regard as one of the most important consequences of career commitment. For instance, Baruch and Winkelmann-Gleed [24] found positive work-related emotions and high career commitment can lead to more intention to stay in the current industry. Kim, Kim, and Yoo [62] proposed that career commitment can enhance the tendency to stay and reduce the turnover intention, based on the results of an empirical study. Similarly, Lee, Carswell, and Allen [25] found that career commitment is positively related to workrelated outcomes, such as job performance and intention to stay, based on a meta-analytic review. Accordingly, this study argues that career decision-making self-efficacy influences intention to stay in the hospitality industry through career commitment, and proposes the following hypothesis:

Hypothesis 3. Career commitment mediates the relationship between career decision-making self-efficacy and intention to stay in the hospitality industry.

\subsection{The Moderating Roles of Intrinsic Motivation}

Intrinsic motivation refers to an individual's natural cognitive tendency toward mastery and inherent interest, instead of external pressures or rewards, and is vital to individual's perception of enjoyment, curiosity, and involvement with regard to one's work [26-29]. Moreover, the intrinsic motivation has been widely discussed by educators because of its association with high-quality learning performance [63,64]. In other words, individuals with high intrinsic motivation will make extra efforts to acquire the knowledge or skills required for their work, and utilize new information or techniques in diverse ways [26,30]. In this vein, when students are working on their internship they have a better chance to understand and assess their own values with regard to intrinsic motivation. Such students can thus not only experience their perceived self-efficacy, but also whether their intrinsic motivation has been promoted, maintained, or reduced. High levels of intrinsic motivation can help to promote a person's ability to make good career decisions, enhance their capability of identifying goals with regard to their future careers, raise their willingness to find and learn information related to their work, improve their ability to find solutions to problems that arise at work, and make them more prepared for their careers. Furthermore, when students have high levels of intrinsic motivation, they tend to have more satisfaction with regard to their internship, more commitment regarding their careers, and thus a greater intention to stay in the hospitality industry. For example, Steele-Johnson, Beauregard, Hoover, and Schmidt [32] showed that the joint effects of intrinsic motivation and self-efficacy can influence individuals' career satisfaction, commitment, and performance. Duffy and Blustein [31] also reported that intrinsic motivation is an important predictor of enhanced career decision-making self-efficacy, career commitment, vocational satisfaction, and future career choices, using a sample of 144 undergraduate students. Finally, Lai and Kapstad [33] found that the positive relationships among self-efficacy, satisfaction, and commitment at work are associated with higher levels of intrinsic motivation, while the positive relationships among career satisfaction, commitment, and exploration or decidedness are also influenced by higher levels of intrinsic motivation, based on an empirical survey. Accordingly, we propose that intrinsic motivation can promote the positive relationship between career decision-making self-efficacy and internship satisfaction, and enhance the 
positive relationship between internship satisfaction and intention to stay in the hospitality industry. We also suggest that intrinsic motivation can raise the positive relationship between decision-making self-efficacy and career commitment, and strengthen the positive relationship between career commitment and intention to stay in the hospitality industry (see Table 1 and Figure 1). As a result, we present the following hypotheses:

Hypothesis 4. Intrinsic motivation moderates the positive relationship between career decisionmaking self-efficacy and internship satisfaction: The relationship is stronger when individuals have relatively high versus low intrinsic motivation.

Hypothesis 5. Intrinsic motivation moderates the positive relationship between internship satisfaction and intention to stay in the hospitality industry: The relationship is stronger when individuals have relatively high versus low intrinsic motivation.

Hypothesis 6. Intrinsic motivation moderates the positive relationship between career decisionmaking self-efficacy and career commitment: The relationship is stronger when individuals have relatively high versus low intrinsic motivation.

Hypothesis 7. Intrinsic motivation moderates the positive relationship between career commitment and intention to stay in the hospitality industry: The relationship is stronger when individuals have relatively high versus low intrinsic motivation.

Table 1. The explanation of the hypotheses.

\begin{tabular}{|c|c|}
\hline Hypotheses & Theoretical Background and References \\
\hline $\begin{array}{l}\text { Hypothesis 1: Career decision-making } \\
\text { self-efficacy is positively related to intention to } \\
\text { stay in the hospitality industry. }\end{array}$ & $\begin{array}{l}\text { Peterson, 2009; Adachi, 2001; Jantzer, et al., } \\
\text { 2009; and Miller et al., } 2009 .\end{array}$ \\
\hline $\begin{array}{l}\text { Hypothesis 2: Internship satisfaction mediates } \\
\text { the relationship between career } \\
\text { decision-making self-efficacy and intention to } \\
\text { stay in the hospitality industry. }\end{array}$ & $\begin{array}{l}\text { Dahling and Thompson, 2013; Wright and } \\
\text { Perrone, 2010; Jadidian and Duffy, 2012; } \\
\text { Komarraju et al., 2014; Chen and Shen, 2012; } \\
\text { Chiang et al., 2005; and Fuller et al., 1996. }\end{array}$ \\
\hline $\begin{array}{l}\text { Hypothesis 3: Career commitment mediates } \\
\text { the relationship between career } \\
\text { decision-making self-efficacy and intention to } \\
\text { stay in the hospitality industry. }\end{array}$ & $\begin{array}{l}\text { Chung, 2002; Jin et al., 2009; Chemers et al., } \\
\text { 2011; Baruch and Winkelmann-Gleed, 2002; } \\
\text { Kim et al., 2012; and Lee et al., } 2000 .\end{array}$ \\
\hline $\begin{array}{l}\text { Hypothesis } 4 \text { : Intrinsic motivation moderates } \\
\text { the positive relationship between career } \\
\text { decision-making self-efficacy and internship } \\
\text { satisfaction. }\end{array}$ & $\begin{array}{l}\text { Steele-Johnson et al., 2000; Duffy and Blustein, } \\
\text { 2005; and Lai and Kapstad, } 2009 .\end{array}$ \\
\hline $\begin{array}{l}\text { Hypothesis } 5 \text { : Intrinsic motivation moderates } \\
\text { the positive relationship between internship } \\
\text { satisfaction and intention to stay in the } \\
\text { hospitality industry. }\end{array}$ & $\begin{array}{l}\text { Duffy and Blustein, 2005; Lai and Kapstad, } \\
\text { 2009; and Conti et al., 1996. }\end{array}$ \\
\hline $\begin{array}{l}\text { Hypothesis 6: Intrinsic motivation moderates } \\
\text { the positive relationship between career } \\
\text { decision-making self-efficacy and career } \\
\text { commitment. }\end{array}$ & $\begin{array}{l}\text { Lai and Kapstad, 2009; Steele-Johnson et al., } \\
\text { 2000; Amabile, 1983; Deci, 1971; and Venkatesh, } \\
2000 .\end{array}$ \\
\hline $\begin{array}{l}\text { Hypothesis } 7 \text { : Intrinsic motivation moderates } \\
\text { the positive relationship between career } \\
\text { commitment and intention to stay in the } \\
\text { hospitality industry. }\end{array}$ & $\begin{array}{l}\text { Duffy and Blustein, 2005; Ryan and Deci, } \\
\text { 2000b; and Lai and Kapstad (2009). }\end{array}$ \\
\hline
\end{tabular}


H1

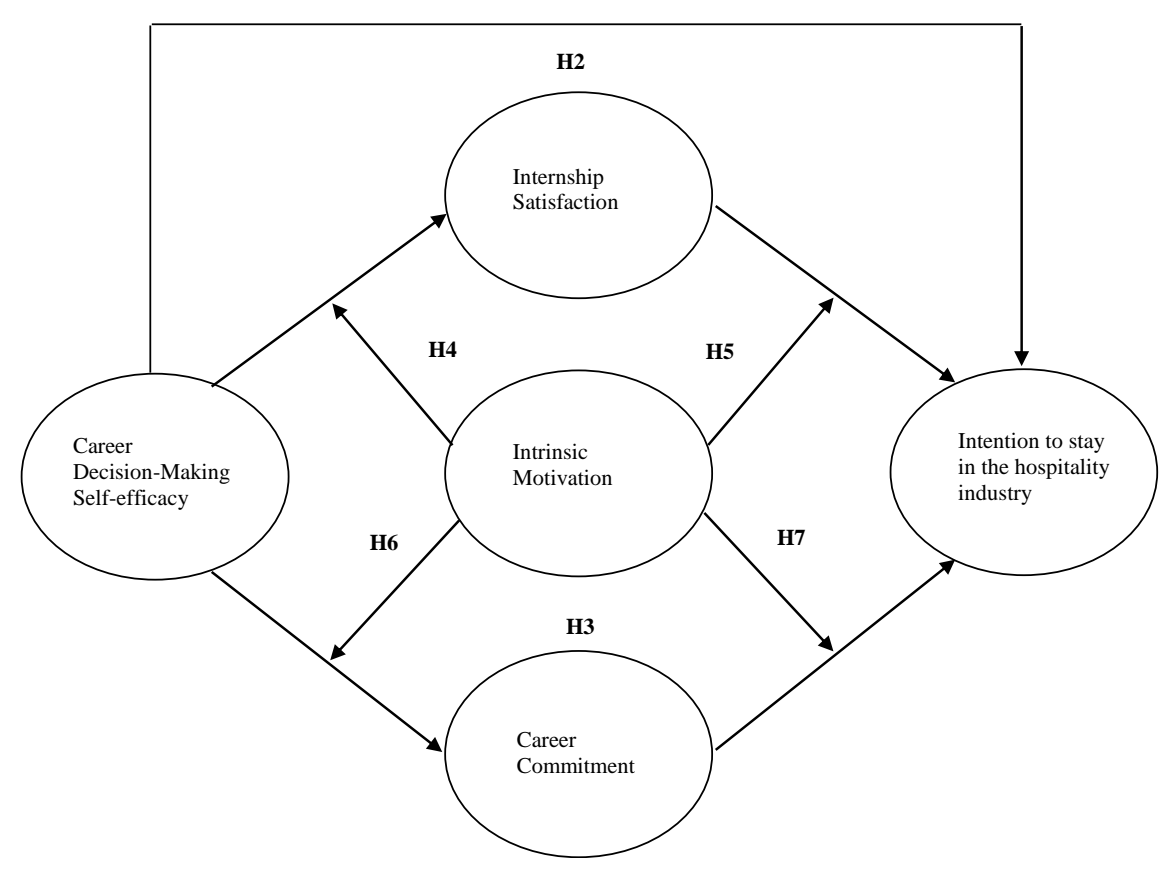

Figure 1. The hypothesized model.

\section{Methodology}

The research method used in this study first aims to develop and broaden the measurement constructs with a focus group interview and the review of the existing literature. Moreover, given the importance of career decision-making self-efficacy, and the relatively limited examination of this topic in hospitality research, we then explore its influences on students' intention to stay in the hospitality industry. Third, we investigate the causal mechanisms of internship satisfaction and career commitment in the relationships between career decision-making self-efficacy and intention to stay in the hospitality industry. Fourth, we further examine the boundary conditions of intrinsic motivation in the relationships among career decision-making self-efficacy, internship satisfaction, career commitment, and intention to stay in the hospitality industry. Finally, discussions and suggestions will be provided based on the results of our empirical study.

\subsection{Instrumentation and Sampling Procedures}

The research design used a quantitative method, and focus groups as well as the existing literature were the two main sources used to develop the constructs in the questionnaire. The measurement items in the preliminary questionnaire were prepared based on the literature, and included the constructs of career decision-making self-efficacy, internship satisfaction, career commitment, intrinsic motivation, and intention to stay in the hospitality industry. In addition, as our sampling target was hospitality students in Taiwan, the items in the questionnaire were translated into Chinese by two bilingual professors and then back-translated into English by another two independent translators using Brislin's [65] forward and backward translation method.

Content validity was examined to estimate how accurately our instrument represents all the facets of the given constructs [66,67]. Three hospitality internship coordinators and five students in the hospitality management department who had just finished internships were asked to examine the survey items. They suggested removing two items from career decision-making self-efficacy and one item from career commitment because of their weak face validity within the constructs. Moreover, two items were reworded due to their unclear wording. As for scale reliability, a pilot test was used to evaluate the internal consistency among the items for each construct based on 40 hospitality students who had just finished 
a half-year internship [68]. The Cronbach's alpha coefficients were 0.90 for career decisionmaking self-efficacy, 0.89 for internship satisfaction, 0.87 for career commitment, 0.92 for intrinsic motivation, and 0.88 for intention to stay in the hospitality industry, and thus showed good reliability.

The samples used in this research were drawn from hospitality management departments in Taiwan, as students in this department are required to complete internships as part of their degrees. In addition, sampling methods were applied in twelve hospitality management departments, focusing on students who had finished their internship within the previous two months. A set of questionnaires of career decision-making selfefficacy [12], internship satisfaction [69], career commitment [20], intrinsic motivation [70], and intention to stay in the hospitality industry [71] were distributed by the researchers and internship coordinators. Before handing out the surveys, we briefly introduced the purpose of our study and told the students how to complete the questionnaire. Completed questionnaires were returned within sealed envelopes to keep the responses confidential. A total of 1000 questionnaires were distributed and 782 were returned, giving a $78.2 \%$ response rate. Demographic information includes gender: female $(426,54.48 \%)$ and male (356, 45.52\%); internship period: half year $(305,39.00 \%)$ and one year $(477,61.00 \%)$; and job characteristics: housekeeping $(227,29.03 \%)$, reception $(158,20.20 \%)$, food and beverage $(289,36.96 \%)$, and others $(108,13.81 \%)$. A summary of the study population is reported in Table 2. The results revealed that when population standard deviation is 0.30 and $Z$ Factor value is 1.96 , the sampling error at $95 \%$ confidence level is 0.02 . In addition, the results of internship location includes stratified sampling of geographical distribution of northern $(283,36.19 \%)$, central $(240,30.69 \%)$, southern $(172,21.99 \%)$, eastern $(71,9.08 \%)$, and outlying islands $(16,2.05 \%)$ in Taiwan, which allows us to validate the sample for representing target population.

Table 2. Summary of the study population.

\begin{tabular}{lllll}
\hline \multicolumn{1}{c}{$\begin{array}{c}\text { Demographic } \\
\text { Information }\end{array}$} & Category & Respondents & Percentage & Accumulation \\
\hline Gender & Female & 426 & $54.48 \%$ & $54.48 \%$ \\
& Male & 356 & $45.52 \%$ & $100.00 \%$ \\
Internship period & Half year & 305 & $39.00 \%$ & $39.00 \%$ \\
& One year & 477 & $61.00 \%$ & $100.00 \%$ \\
Internship location & Northern & 283 & $36.19 \%$ & $36.19 \%$ \\
& Central & 240 & $30.69 \%$ & $66.88 \%$ \\
& Southern & 172 & $21.99 \%$ & $88.87 \%$ \\
& Eastern & 71 & $9.08 \%$ & $97.95 \%$ \\
& Outlying & 16 & $2.05 \%$ & $100.00 \%$ \\
& islands & & & \\
Job characteristics & Housekeeping & 227 & $29.03 \%$ & $29.03 \%$ \\
& Reception & 158 & $20.20 \%$ & $49.23 \%$ \\
& Food and & 289 & $36.96 \%$ & $86.19 \%$ \\
& Beverage & 108 & $13.81 \%$ & $100.00 \%$ \\
\hline
\end{tabular}

Note: $n=782$.

\subsection{Measures}

Career Decision-Making Self-efficacy. Career decision-making self-efficacy was measured with the 25-item short form of the five career-choice competencies [12]. Two items were removed due to their weak face validity and two items were reworded for their unclear wording, based on the suggestions of the focus group. Students expressed their degree of confidence with a five-point Likert scale, ranging from "no confidence at all" (1) to "complete confidence" (5). Sample items for the five competencies are as follows: accurate 
self-appraisal (e.g., "I can determine what my ideal job would be"), goal selection (e.g., "I can make a career decision and then not worry about whether it was right or wrong"), gathering occupational information (e.g., "I can talk with a person already employed in the field I am interested in"), problem-solving (e.g., "I can persistently work at my major or career goal even when I get frustrated"), and making plans for the future (e.g., "I can determine the steps I need to take to successfully complete my chosen major").

Internship Satisfaction. We used the Michigan Organizational Assessment Questionnaire [69] to measure the students' internship satisfaction with three items. A five-point Likert scale was used, ranging from "strongly disagree" (1) to "strongly agree" (5), and a sample item is "All in all, I am satisfied with my internship".

Career Commitment. Career commitment was assessed using Blau's [20] measurement with seven items, and one item was removed for lack of face validity. The respondents used a five-point Likert scale, ranging from "strongly disagree" (1) to "strongly agree" (5), to reflect their career commitment status, with a sample item being "I want a career in this profession".

Intrinsic motivation. We measured intrinsic motivation with three items developed by Shalley, Gilson, and Blum [70]. The students again responded with a five-point Likert scale, ranging from "strongly disagree" (1) to "strongly agree" (5). A sample item is "I take pride in doing my internship as well as I can".

Intention to stay in the hospitality industry. We used three items from Zopiatis and Theocharous [71] to measure students' intention to stay in the hospitality industry. Students rated their intention to stay in the hospitality industry using a five-point Likert scale, ranging from "strongly disagree" (1) to "strongly agree" (5), with a sample item being "After the completion of my internship experience, I see myself as having a future in the hospitality industry".

\subsection{Analytical Strategy}

Composite reliability (CR) was used to measure the internal consistency reliability $[72,73]$, and the average variance extracted (AVE) was used to measure the convergent validity [72,73]. Furthermore, we adopted Anderson and Gerbing's [74] two-step strategy to investigate the overall model fit with Confirmatory Factor Analysis (CFA), and explore our hypotheses with Structural Equation Modeling (SEM). According to Novikova, Richman, Supekar, Barnard-Brak, and Hall [75], SEM has superior advantages over traditional analysis methods in explicit evaluation of measurement error for statistical procedure, enabling the clarification and explanation of the broader scope of relationships between latent (unobserved) constructs through observed variables and ensuring the possibility of investigating structure causality along with assessment to fit the statistical data in the hypothesized model. The maximum-likelihood estimation software AMOS 22.0 [76] was used (in Table 3), and the fit indices of the chi-square $\left(\chi^{2}\right)$, degrees of freedom (df), $\chi^{2} / d f$, goodness-of-fit index (GFI), adjusted goodness-of-fit index (AGFI), comparative fix index (CFI), standardized root mean square residual (SRMR), and the root mean square error of approximation (RMSEA) were adopted to examine the overall model fit [77].

Table 3. Fit indices.

\begin{tabular}{|c|c|c|c|}
\hline Fit Indices & Model Value & Reference Value & Overall Model Fit \\
\hline$x^{2} / \mathrm{df}$ & 3.87 & $<5.00$ & Yes \\
\hline GFI & 0.91 & $>0.90$ & Yes \\
\hline AGFI & 0.90 & $>0.90$ & Yes \\
\hline CFI & 0.91 & $>0.90$ & Yes \\
\hline Standardized RMR & 0.05 & $<0.05$ & Yes \\
\hline RMSEA & 0.05 & $<0.10$ & Yes \\
\hline NCP & 871.32 & $\begin{array}{l}>\mathrm{NCP} \text { saturated }(0.00) \\
<\mathrm{NCP} \text { independence }(17,476.65)\end{array}$ & Yes \\
\hline FMIN & 3.15 & $\begin{array}{l}>\text { FMIN saturated }(0.00) \\
<\text { FMIN independence }(22.93)\end{array}$ & Yes \\
\hline
\end{tabular}




\section{Results}

Table 4 reveals the means, standard deviations, correlations, and square root of the AVEs of the constructs. Career decision-making self-efficacy was positively related to internship satisfaction $(\mathrm{r}=0.70, p<0.01)$, career commitment $(\mathrm{r}=0.65, p<0.01)$, intrinsic motivation $(\mathrm{r}=0.47, p<0.01)$, and intention to stay in the hospitality industry $(\mathrm{r}=0.68$, $p<0.01$ ). Internship satisfaction, career commitment, and intrinsic motivation were all positively related to intention to stay in the hospitality industry $(\mathrm{r}=0.60, p<0.01 ; \mathrm{r}=0.57$, $p<0.01 ; \mathrm{r}=0.43, p<0.01$, respectively), while internship satisfaction was positively related to career commitment and intrinsic motivation $(\mathrm{r}=0.64, p<0.01 ; \mathrm{r}=0.56, p<0.01$, respectively).

Table 4. Means, standard deviations, reliabilities, and correlations of constructs.

\begin{tabular}{|c|c|c|c|c|c|c|c|c|c|}
\hline & Mean & S.D. & 1 & 2 & 3 & 4 & 5 & 6 & 7 \\
\hline 1. Age & 21.2 & 0.84 & - & & & & & & \\
\hline 2. Gender & 1.45 & 0.49 & $-0.19^{* *}$ & - & & & & & \\
\hline $\begin{array}{l}\text { 3. Career decision-making } \\
\text { self-efficacy }\end{array}$ & 5.47 & 0.89 & 0.03 & 0.01 & $(0.77)$ & & & & \\
\hline 4. Internship satisfaction & 5.49 & 0.88 & $0.12^{* *}$ & 0.03 & $0.70 * *$ & $(0.81)$ & & & \\
\hline 5. Career commitment & 5.15 & 0.97 & $0.10^{* *}$ & 0.02 & $0.65 * *$ & $0.64^{* *}$ & $(0.73)$ & & \\
\hline 6. Intrinsic motivation & 5.48 & 0.71 & $0.09 *$ & -0.02 & $0.47 * *$ & $0.56^{* *}$ & $0.35^{* *}$ & $(0.75)$ & \\
\hline $\begin{array}{l}\text { 7. Intention to stay in the } \\
\text { hospitality industry }\end{array}$ & 5.45 & 0.85 & 0.00 & -0.01 & $0.68 * *$ & $0.60 * *$ & $0.57^{* *}$ & $0.43^{* *}$ & (0.73) \\
\hline
\end{tabular}

Note: $(1) * p<0.05 ; * * p<0.01$ (two-tailed); $n=782$. (2) Square root of the AVEs for discriminant validity are in parentheses along the diagonal.

\subsection{Measurement Model}

We conducted CFA analyses on the constructs of career decision-making self-efficacy, internship satisfaction, career commitment, and intention to stay in the hospitality industry (see Table 5). The results showed that the Cronbach's $\alpha$ and CRs of each construct were both higher than the 0.60 threshold value (ranged from 0.75 to 0.92 , and 0.77 to 0.96 ), thus showing evidence for good internal consistency reliability [72,73]. Furthermore, the AVEs of each construct ranged from 0.53 to 0.66 , higher than the 0.50 threshold [72,73], and the factor loadings of all items in the four-factor model were significant (all $p<0.001$ ), showing the good convergent validity of our measurement model.

Table 5. Coefficients for the measurement model.

\begin{tabular}{|c|c|c|c|c|c|c|c|c|}
\hline Construct & $\begin{array}{l}\text { No. of } \\
\text { Items }\end{array}$ & Cronbach's $\alpha$ & Variable & $\begin{array}{c}\text { Standardized } \\
\text { Factor Loadings }\end{array}$ & S.E. & $\begin{array}{c}\text { C.R. } \\
\text { (t-Value) }\end{array}$ & AVE & $\begin{array}{l}\text { Composite } \\
\text { Reliability }\end{array}$ \\
\hline $\begin{array}{l}\text { Career } \\
\text { decision-making } \\
\text { self-efficacy }\end{array}$ & 18 & 0.92 & $\begin{array}{l}\text { CDMSE } 1 \\
\text { CDMSE } 2 \\
\text { CDMSE } 3 \\
\text { CDMSE } 4 \\
\text { CDMSE } 5 \\
\text { CDMSE } 6 \\
\text { CDMSE } 7 \\
\text { CDMSE } 8 \\
\text { CDMSE } 9 \\
\text { CDMSE } 10 \\
\text { CDMSE } 11 \\
\text { CDMSE } 12 \\
\text { CDMSE } 13 \\
\text { CDMSE } 14 \\
\text { CDMSE } 15 \\
\text { CDMSE } 16 \\
\text { CDMSE } 17 \\
\text { CDMSE } 18\end{array}$ & $\begin{array}{l}0.76 \\
0.72 \\
0.70 \\
0.76 \\
0.80 \\
0.78 \\
0.81 \\
0.78 \\
0.70 \\
0.81 \\
0.75 \\
0.80 \\
0.87 \\
0.76 \\
0.79 \\
0.82 \\
0.73 \\
0.73\end{array}$ & $\begin{array}{l}- \\
0.05 \\
0.05 \\
0.06 \\
0.06 \\
0.06 \\
0.06 \\
0.06 \\
0.05 \\
0.05 \\
0.05 \\
0.06 \\
0.06 \\
0.06 \\
0.06 \\
0.06 \\
0.05 \\
0.06\end{array}$ & 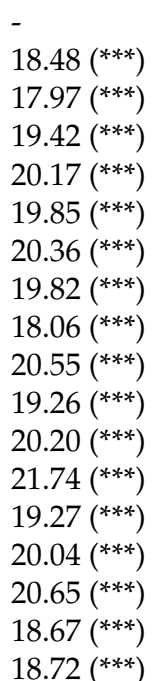 & 0.60 & 0.96 \\
\hline
\end{tabular}


Table 5. Cont.

\begin{tabular}{|c|c|c|c|c|c|c|c|c|}
\hline Construct & $\begin{array}{l}\text { No. of } \\
\text { Items }\end{array}$ & Cronbach's $\alpha$ & Variable & $\begin{array}{c}\text { Standardized } \\
\text { Factor Loadings }\end{array}$ & S.E. & $\begin{array}{c}\text { C.R. } \\
\text { (t-Value) }\end{array}$ & AVE & $\begin{array}{l}\text { Composite } \\
\text { Reliability }\end{array}$ \\
\hline \multirow{3}{*}{$\begin{array}{l}\text { Internship } \\
\text { satisfaction }\end{array}$} & \multirow[t]{3}{*}{3} & \multirow[t]{3}{*}{0.82} & IS 1 & 0.79 & - & - & \multirow[t]{3}{*}{0.66} & \multirow[t]{3}{*}{0.85} \\
\hline & & & IS 2 & 0.86 & 0.05 & $25.59\left(^{* * *}\right)$ & & \\
\hline & & & IS 3 & 0.78 & 0.05 & $22.98\left(^{* * *}\right)$ & & \\
\hline \multirow{6}{*}{$\begin{array}{l}\text { Career } \\
\text { commitment }\end{array}$} & \multirow[t]{6}{*}{6} & \multirow[t]{6}{*}{0.86} & CC 1 & 0.73 & - & - & \multirow[t]{6}{*}{0.54} & \multirow[t]{6}{*}{0.88} \\
\hline & & & CC 2 & 0.72 & 0.05 & $18.67\left(^{* * *}\right)$ & & \\
\hline & & & $\mathrm{CC} 3$ & 0.72 & 0.05 & $19.12\left(^{* * *}\right)$ & & \\
\hline & & & CC 4 & 0.71 & 0.05 & $\left.17.85{ }^{* * *}\right)$ & & \\
\hline & & & CC 5 & 0.80 & 0.04 & $21.17\left(^{* * *}\right)$ & & \\
\hline & & & CC 6 & 0.73 & 0.05 & $\left.19.96{ }^{* * *}\right)$ & & \\
\hline \multirow{3}{*}{$\begin{array}{l}\text { Intrinsic } \\
\text { motivation }\end{array}$} & \multirow[t]{3}{*}{3} & \multirow[t]{3}{*}{0.83} & IM 1 & 0.82 & - & - & \multirow[t]{3}{*}{0.64} & \multirow[t]{3}{*}{0.84} \\
\hline & & & IM 2 & 0.87 & 0.05 & $21.99\left(^{* * *}\right)$ & & \\
\hline & & & IM 3 & 0.70 & 0.05 & $19.74\left(^{* * *}\right)$ & & \\
\hline \multirow{3}{*}{$\begin{array}{l}\text { Intention to stay } \\
\text { in the hospitality } \\
\text { industry }\end{array}$} & \multirow[t]{3}{*}{3} & \multirow[t]{3}{*}{0.75} & ITSHI 1 & 0.71 & - & - & \multirow[t]{3}{*}{0.53} & \multirow[t]{3}{*}{0.77} \\
\hline & & & ITSHI 2 & 0.77 & 0.06 & $\left.18.799^{(* *}\right)$ & & \\
\hline & & & ITSHI 3 & 0.70 & 0.06 & $16.78\left(^{* * *}\right)$ & & \\
\hline
\end{tabular}

Note: $(1)^{* * *} p<0.001$ (two-tailed); $n=782 .(2) \chi^{2}=1852.70, \mathrm{df}=485, \chi^{2} / \mathrm{df}=3.82, \mathrm{GFI}=0.92, \mathrm{AGFI}=0.91, \mathrm{CFI}=0.91$, and SRMR $=0.05$.

In addition, discriminant validity of constructs were appraised based on a series of $\chi^{2}$ difference tests through pairwise CFAs. This approach first used two-dimensional CFA for each pair of constructs, and then collapsed all items into a single-factor CFA model. As can be seen in Table 6 , the $\chi^{2}$ difference tests generate a significant result $\left(\Delta \chi^{2}>6.64\right.$, $p<0.01$ ) for each pair of constructs. Accordingly, compared with original constructs with two-dimensions, the single-factor CFA model revealed a significant deterioration of the model fit. These empirical results provided support for discriminant validity [74].

Table 6. Discriminant validity with chi-square difference.

\begin{tabular}{lcccc}
\hline & $\mathbf{1}$ & $\mathbf{2}$ & $\mathbf{3}$ & $\mathbf{4}$ \\
\hline 1. Career decision-making self-efficacy & & & & \\
2. Internship satisfaction & 120.32 & & & \\
3. Career commitment & 113.56 & 198.42 & & \\
4. Intrinsic motivation & 186.23 & 143.87 & 104.38 & \\
5. Intention to stay in the hospitality industry & 209.14 & 263.59 & 172.43 & 89.71 \\
\hline
\end{tabular}

Note: (1) Chi-square difference tests (all tests $\triangle \mathrm{df}=1$ ); $n=782$. (2) $\triangle \chi^{2}>6.64, p<0.01$.

\subsection{Structural Model}

The results of the SEM analysis revealed that our proposed structural model has adequate model fit $\left(\chi^{2}=1568.12, \mathrm{df}=400, \chi^{2} / \mathrm{df}=3.92, \mathrm{GFI}=0.91\right.$, AGFI $=0.90, \mathrm{CFI}=0.91$, and SRMR = 0.05). Based on Baron and Kenny's [78] suggestion, we adopted a causal steps strategy to explore the state of mediation. In Table 4, the correlation coefficients show that career decision-making self-efficacy is significantly and positively related to intention to stay in the hospitality industry $(\mathrm{r}=0.68, p<0.01)$, internship satisfaction $(\mathrm{r}=0.70, p<0.01)$, and career commitment $(\mathrm{r}=0.65, p<0.01)$. Moreover, the direct positive effect of career decision-making self-efficacy on intention to stay in the hospitality industry was significant (standardized direct effect $=0.40, p<0.01$, see Figure 2), as were the direct positive effects of career decision-making self-efficacy on internship satisfaction (standardized direct effect $=0.78, p<0.01$ ), and career decision-making self-efficacy on career commitment (standardized direct effect $=0.78, p<0.01$ ). We thus conclude that Hypotheses 1 was supported and met the first state of mediation. 


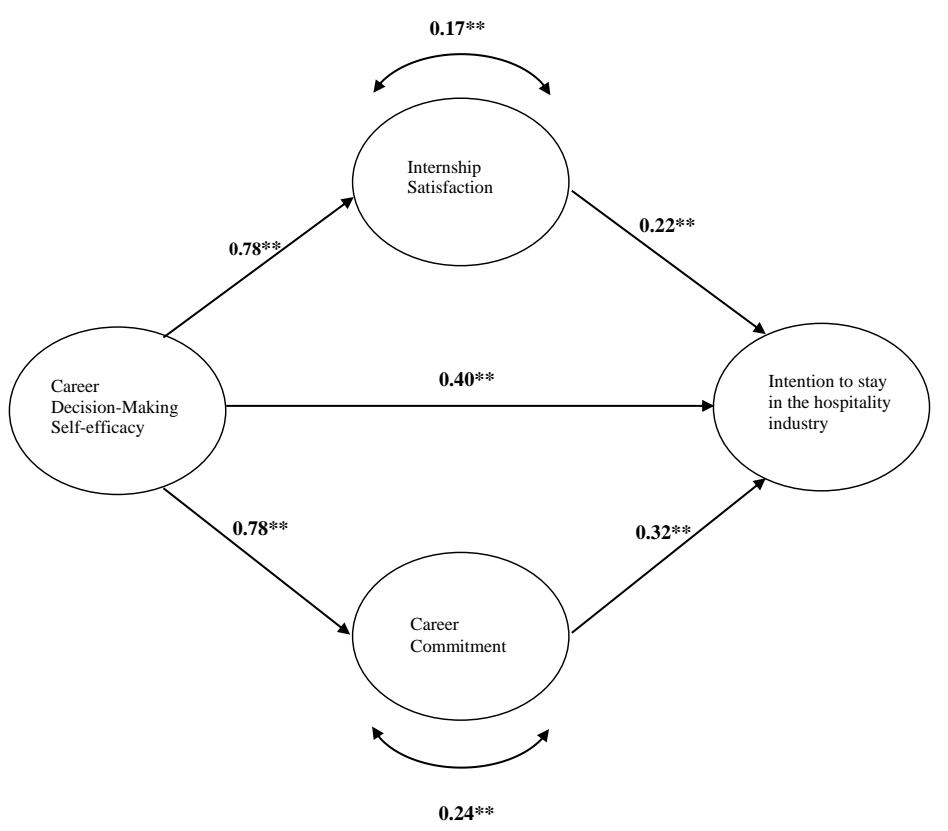

Figure 2. Structural equation modeling for the hypothesized model. Note: ${ }^{* *} p<0.01 ; n=782$.

As for Hypotheses 2 and 3 (see Table 4), the correlation coefficient indicated that internship satisfaction was significantly and positively related to intention to stay in the hospitality industry $(\mathrm{r}=0.60, p<0.01)$, as was career commitment $(\mathrm{r}=0.57, p<0.01)$. Furthermore, the direct positive effects of internship satisfaction on intention to stay in the hospitality industry (standardized direct effect $=0.22, p<0.05$, see Figure 2), as well as that of career commitment (standardized direct effect $=0.32, p<0.01$ ), were both significant. Accordingly, the second state of mediation was supported. To further verify the indirect effects of the structural model, we adopted the Sobel [79] test to validate our results (in Table 7). The results revealed the indirect effect of career decision-making self-efficacy on intention to stay in the hospitality industry via the mediating roles of internship satisfaction and career commitment, which was verified by the Sobel tests (internship satisfaction, $\mathrm{Z}=4.29, p<0.01$; career commitment, $\mathrm{Z}=5.74, p<0.01$ ). Therefore, the results supported that internship satisfaction and career commitment mediated the effect of career decisionmaking self-efficacy on intention to stay in the hospitality industry. In addition, we also conducted percentile bootstrapping and bias-corrected percentile bootstrapping with a $95 \%$ confidence interval using 5000 bootstrap samples [80]. Following the recommendation of Preacher and Hayes [81], we calculated the confidence interval between the lower and upper bounds and used this to examine the indirect effects. As the results show in Table 8, bootstrapping analyses provide evidence for the significant mediating roles of internship satisfaction (standardized indirect effect $=0.17, p<0.05$ ) and career commitment (standardized indirect effect $=0.24, p<0.01$ ) in the relationship between career decisionmaking self-efficacy and intention to stay in the hospitality industry. Hypotheses 2 and 3 were thus both supported.

Table 7. Sobel tests of the statistical significance of mediation.

\begin{tabular}{|c|c|c|c|c|c|}
\hline Independent Variable & Mediator Variable & $\begin{array}{c}\text { Dependent } \\
\text { Variable }\end{array}$ & $\begin{array}{l}\text { Standardized } \\
\text { Indirect Effect }\end{array}$ & Z Value & $\begin{array}{l}\text { Two Tailed } \\
\text { Significance }\end{array}$ \\
\hline $\begin{array}{l}\text { Career decision-making } \\
\text { self-efficacy } \rightarrow\end{array}$ & $\begin{array}{l}\text { Internship } \\
\text { satisfaction } \rightarrow\end{array}$ & $\begin{array}{l}\text { Intention to stay in the } \\
\text { hospitality industry }\end{array}$ & $(0.78) \times(0.22)=0.17$ & 4.29 & $* *$ \\
\hline $\begin{array}{l}\text { Career decision-making } \\
\text { self-efficacy } \rightarrow\end{array}$ & $\begin{array}{c}\text { Career } \\
\text { commitment } \rightarrow\end{array}$ & $\begin{array}{l}\text { Intention to stay in the } \\
\text { hospitality industry }\end{array}$ & $(0.78) \times(0.32)=0.24$ & 5.74 & $* *$ \\
\hline
\end{tabular}

Note: ${ }^{* *} p<0.01 ; n=782$. 
Table 8. Standardized direct, indirect, and total effects of the structural model.

\begin{tabular}{|c|c|c|c|c|c|c|c|c|c|}
\hline & \multirow{3}{*}{$\begin{array}{c}\text { Point } \\
\text { Estimate }\end{array}$} & \multirow{2}{*}{\multicolumn{2}{|c|}{$\begin{array}{l}\text { Product of } \\
\text { Coefficients }\end{array}$}} & \multicolumn{6}{|c|}{ Bootstrapping } \\
\hline & & & & \multicolumn{2}{|c|}{ Percentile 95\% CI } & \multicolumn{2}{|c|}{$\begin{array}{c}\text { Bias-Corrected } \\
\text { Percentile 95\% CI }\end{array}$} & \multicolumn{2}{|c|}{$\begin{array}{l}\text { Two-Tailed } \\
\text { Significance }\end{array}$} \\
\hline & & SE & $\mathbf{Z}$ & Lower & Upper & Lower & Upper & & \\
\hline \multicolumn{10}{|c|}{ Standardized Direct Effects } \\
\hline $\begin{array}{l}\text { Career decision-making self-efficacy } \rightarrow \\
\text { Intention to stay in the hospitality industry }\end{array}$ & 0.40 & 0.06 & 5.34 & 0.23 & 0.57 & 0.20 & 0.55 & 0.00 & $(* *)$ \\
\hline $\begin{array}{c}\text { Career decision-making self-efficacy } \rightarrow \\
\text { Internship satisfaction }\end{array}$ & 0.78 & 0.04 & 16.67 & 0.72 & 0.83 & 0.72 & 0.83 & 0.00 & $(* *)$ \\
\hline $\begin{array}{c}\text { Career decision-making self-efficacy } \rightarrow \\
\text { Career commitment }\end{array}$ & 0.78 & 0.06 & 14.80 & 0.59 & 0.84 & 0.59 & 0.84 & 0.00 & $(* *)$ \\
\hline $\begin{array}{c}\text { Internship satisfaction } \rightarrow \text { Intention to stay } \\
\text { in the hospitality industry }\end{array}$ & 0.22 & 0.05 & 3.86 & 0.03 & 0.38 & 0.04 & 0.38 & 0.02 & $\left({ }^{*}\right)$ \\
\hline $\begin{array}{c}\text { Career commitment } \rightarrow \text { Intention to stay in } \\
\text { the hospitality industry }\end{array}$ & 0.32 & 0.05 & 5.22 & 0.11 & 0.50 & 0.12 & 0.51 & 0.00 & $(* *)$ \\
\hline \multicolumn{10}{|c|}{ Standardized Indirect Effects } \\
\hline $\begin{array}{c}\text { Career decision-making self-efficacy } \rightarrow \\
\text { Internship satisfaction } \rightarrow\end{array}$ & 0.17 & 0.05 & 3.29 & 0.02 & 0.30 & 0.02 & 0.30 & 0.03 & $(*)$ \\
\hline $\begin{array}{l}\text { Intention to stay in the hospitality industry } \\
\text { Career decision-making self-efficacy } \rightarrow\end{array}$ & & & & & & & & & \\
\hline Career commitment $\rightarrow$ & 0.24 & 0.05 & 4.25 & 0.06 & 0.39 & 0.06 & 0.39 & 0.00 & $(* *)$ \\
\hline \multicolumn{10}{|c|}{ Standardized Total Effects } \\
\hline $\begin{array}{l}\text { Career decision-making self-efficacy } \rightarrow \\
\text { Intention to stay in the hospitality industry }\end{array}$ & 0.81 & 0.04 & 17.56 & 0.73 & 0.88 & 0.73 & 0.88 & 0.00 & $(* *)$ \\
\hline $\begin{array}{c}\text { Career decision-making self-efficacy } \rightarrow \\
\text { Internship satisfaction }\end{array}$ & 0.78 & 0.04 & 16.67 & 0.72 & 0.83 & 0.72 & 0.83 & 0.00 & $(* *)$ \\
\hline $\begin{array}{c}\text { Career decision-making self-efficacy } \rightarrow \\
\text { Career commitment }\end{array}$ & 0.78 & 0.06 & 14.80 & 0.59 & 0.84 & 0.59 & 0.84 & 0.00 & $(* *)$ \\
\hline $\begin{array}{c}\text { Internship satisfaction } \rightarrow \text { Intention to stay } \\
\text { in the hospitality industry }\end{array}$ & 0.22 & 0.05 & 3.86 & 0.03 & 0.38 & 0.04 & 0.38 & 0.02 & $\left(^{*}\right)$ \\
\hline $\begin{array}{c}\text { Career commitment } \rightarrow \text { Intention to stay in } \\
\text { the hospitality industry }\end{array}$ & 0.32 & 0.05 & 5.22 & 0.11 & 0.50 & 0.12 & 0.51 & 0.00 & $(* *)$ \\
\hline
\end{tabular}

Note: Standardized estimating of 5000 bootstrap samples, ${ }^{*} p<0.05,{ }^{* *} p<0.01 ; n=782$.

To examine the moderating roles of intrinsic motivation, multi-group models were used to investigate Hypotheses 4-7. We first fixed the path coefficient from career decisionmaking self-efficacy to internship satisfaction to be equal, and then let the other path coefficients be freely estimated with regard to the high and low intrinsic motivation groups. Accordingly, the chi-square difference between the unconstrained and constrained models was utilized to explore Hypothesis 4 . As shown in Table 9, the chi-square difference was significant $\left(\Delta \chi^{2}(1)=8.42, p<0.01\right)$ and the path coefficient from career decision-making selfefficacy to internship satisfaction was $0.70(p<0.01)$ in the high intrinsic motivation group and $0.48(p<0.01)$ in the low intrinsic motivation one. The positive relationship between career decision-making self-efficacy and internship satisfaction was thus stronger among the individuals with high intrinsic motivation than those with low intrinsic motivation, supporting Hypothesis 4 . We further fixed the path coefficient from internship satisfaction to intention to stay in the hospitality industry to be equal and let the other path coefficients be freely estimated in both groups. The chi-square difference was significant $\left(\Delta \chi^{2}(1)=7.56\right.$, $p<0.01$ ), and the positive relationship between internship satisfaction and intention to stay in the hospitality industry was stronger in the high intrinsic motivation group than in the low intrinsic motivation one, thus supporting Hypothesis 5. 
Table 9. Measurement invariance of the two-group structural model for moderating effects.

\begin{tabular}{|c|c|c|c|c|c|c|c|}
\hline & \multicolumn{2}{|c|}{$\begin{array}{l}\text { Low intrinsic Motivation } \\
\text { Group }(N=355)\end{array}$} & \multicolumn{2}{|c|}{$\begin{array}{l}\text { High Intrinsic Motivation } \\
\text { Group }(N=427)\end{array}$} & \multirow{2}{*}{$\begin{array}{c}\text { Constrained } \\
\text { Model }\end{array}$} & \multirow{2}{*}{$\begin{array}{c}\text { Unconstrained } \\
\text { Model }\end{array}$} & \multirow{2}{*}{$\begin{array}{c}\triangle \chi^{2} \\
(\triangle \mathrm{df}=\mathbf{1})\end{array}$} \\
\hline & $\begin{array}{l}\text { Standardized } \\
\text { Coefficients }\end{array}$ & Z-Value & $\begin{array}{l}\text { Standardized } \\
\text { Coefficients }\end{array}$ & Z-Value & & & \\
\hline $\begin{array}{l}\text { Career decision-making } \\
\text { self-efficacy } \rightarrow \\
\text { Internship satisfaction }\end{array}$ & 0.48 & $5.95^{* *}$ & 0.70 & $9.63 * *$ & 1576.54 & 1568.12 & $8.42 * *$ \\
\hline $\begin{array}{l}\text { Career decision-making } \\
\text { self-efficacy } \rightarrow \\
\text { Career commitment } \\
\text { Internship satisfaction }\end{array}$ & 0.44 & $5.41^{* *}$ & 0.75 & 8.59 ** & 1574.41 & 1568.12 & $6.29 *$ \\
\hline $\begin{array}{l}\rightarrow \\
\text { Intention to stay in the } \\
\text { hospitality industry }\end{array}$ & 0.19 & $2.28 *$ & 0.30 & $3.93 * *$ & 1575.68 & 1568.12 & 7.56 ** \\
\hline $\begin{array}{l}\text { Career commitment } \rightarrow \\
\text { Intention to stay in the } \\
\text { hospitality industry }\end{array}$ & 0.16 & $2.99 *$ & 0.31 & $3.62 * *$ & 1577.13 & 1568.12 & $9.01^{* *}$ \\
\hline
\end{tabular}

Note: ${ }^{*} p<0.05,{ }^{* *} p<0.01 ; n=782$

We also fixed the path coefficient from career decision-making self-efficacy to career commitment to be equal and left the other path coefficients to be freely calculated in both groups. The chi-square difference was significant $\left(\Delta \chi^{2}(1)=6.29, p<0.05\right)$, and the positive relationship between career decision-making self-efficacy and career commitment was stronger in the high intrinsic motivation group than in the low intrinsic motivation group, and thus Hypothesis 6 was supported. We then fixed the path coefficient from career commitment to intention to stay in the hospitality industry, and the other path coefficients were calculated freely for the high and low intrinsic motivation groups. The results in Table 9 show the chi-square difference was significant $\left(\Delta \chi^{2}(1)=9.01, p<0.01\right)$ between the unconstrained and constrained models, and the positive relationship between career commitment and intention to stay in the hospitality industry was stronger in the high intrinsic motivation group than in the low intrinsic motivation one. Accordingly, Hypothesis 7 was supported.

\section{General Discussion}

\subsection{Theoretical Implications}

The results of this study contribute to hospitality research in several aspects. First, on the basis of Bandura's [11] social cognitive theory and Betz et al.'s [12] theory of career decision-making self-efficacy, our study is the first work to consider the application of both theories in the field of hospitality internship research. The results support that five competencies of career decision-making self-efficacy (accurate self-appraisal, goal selection, gathering occupational information, problem-solving, and making plans for the future) can together influence students' intention to stay in the hospitality industry. In other words, students taking part in internships who have high career decision-making self-efficacy tend to make more efforts regarding the decision process, persist in finding solutions for any problems they face, and make more effort to engage in their career development, and thus are more likely to be successful in this regard $[17,54,82]$.

Second, this study proposed an integrated theoretical model to explore the relationships among the constructs using SEM analyses. Internship satisfaction, students' affective attachment toward their internship [51], and career commitment, commitment regarding their devotion, and aspiration to work in a particular field [20], are thus introduced to assess their influences in these causal chain relationships. In line with social cognitive theory [11], the results show that both internship satisfaction and career commitment mediate the relationships between career decision-making self-efficacy and intention to stay in the hospitality industry. Comparing the results obtained in the research with those pre- 
viously reported by other researchers, our study are congruent with those of Peterson [48], Adachi [49], and Jantzer, Stalides, and Rottinghaus [50], which demonstrated that career decision-making self-efficacy could be used to improve intention to stay in the industry; those of Dahling and Thompson [55], Wright and Perrone [56], and Jadidian and Duffy [21], which revealed that students' career self-efficacy can raise their internship satisfaction; and those of Chen and Shen [3], Chiang, Back, and Canter [57], and Fuller, Hester, Dickson, Allison, and Birdseye [22], which found student internship satisfaction is associated with greater intention to stay in the focal industry. Moreover, our study results are also in line with those of Chung [23], Jin, Watkins, and Yuen [60], and Chemers, Zurbriggen, Syed, Goza, and Bearman [61], which demonstrated that career decision-making self-efficacy can influence career commitment; and those of Baruch and Winkelmann-Gleed [24], Kim, Kim, and Yoo [62], and Lee, Carswell, and Allen [25], which revealed that intention to stay in an industry can be regarded as one of the most important consequences of career commitment. Most of all, these prior studies had only investigated the single relationships among internship satisfaction, career commitment, career decision-making self-efficacy, and intention to stay in the hospitality industry, which lacks an integrative perspective to discover the causal linkages among the aforementioned variables. Therefore, our study results provide an empirical answer to link internship satisfaction and career commitment in the integrated model which mediate the relationship between students' career decision-making self-efficacy and their intention to stay in the hospitality industry, thus filling a missing piece within hospitality research. That is, if students have high career decision-making self-efficacy, then this will lead to more satisfaction with regard to their internship and greater commitment with regard to their career, and both of these help to predict their intention to remain in the hospitality industry.

Finally, the findings also provide a new perspective on the moderating roles of intrinsic motivation in the relationships among career decision-making self-efficacy, internship satisfaction, career commitment, and intention to stay in the hospitality industry. As intrinsic motivation represents an individual's natural cognitive tendency toward mastery and inherent interest in certain tasks [26-29], individuals with high intrinsic motivation tend to make more effort to obtain the skills required for their work and then utilize them in more innovative and productive ways $[26,30]$. Comparing the obtained research results with those antecedently reported by other studies, our study results are consistent with those of Steele-Johnson, Beauregard, Hoover, and Schmidt [32], which demonstrated that intrinsic motivation can promote the positive relationship between self-efficacy and satisfaction with performance; that of Duffy and Blustein [31], which revealed that intrinsic motivation can enhance the positive relationship between career decision-making selfefficacy, career commitment, vocational satisfaction, and future career intention to stay; and that of Lai and Kapstad [33], which found that intrinsic motivation can raise the positive relationship between decision-making self-efficacy, satisfaction, commitment, and intention to stay at work. Specifically, these previous studies only revealed that intrinsic motivation may raise the singular path regarding the positive relationship between decisionmaking self-efficacy and career commitment, and the positive relationship between career commitment and intention to stay [31-33]; however, they are short of deep understanding of the body of knowledge in hospitality with empirical data. Accordingly, it is noteworthy that our study results provide a brand-new perspective with an incorporated model that enables intrinsic motivation to interact with the positive relationships among students' career decision-making self-efficacy, internship satisfaction, career commitment, and their intention to stay in the hospitality industry, and such relationships are stronger when students have relatively high versus low intrinsic motivation. In this way, this study thus offers clarity for the vital moderating roles of intrinsic motivation in the integrated framework for useful contributions in hospitality settings. In relation to this, our findings indicate that students can have the opportunity to assess their intrinsic motivation by taking part in an internship, as this can raise the positive relationships among career decisionmaking self-efficacy, internship satisfaction, and career commitment, and strengthen the 
positive relationships among internship satisfaction, career commitment, and intention to stay in the hospitality industry.

\subsection{Practical Implications}

The hospitality industry is one of the most rapidly growing sectors in the global economy [83]. Moreover, the degrees to which a person identifies with and feels they have self-efficacy toward their hospitality career play a crucial role in work setting selection, and can be used to predict future career commitment, satisfaction, and intention to remain in the industry. Consequently, both human resource managers and line managers in the hospitality sector should focus on providing appropriate training programs to raise the self-efficacy of interns and employees. For example, a good learning system can provide employees with more chances to enhance their capabilities, knowledge, and skills for work $[84,85]$. In addition, job rotation can also be used to broaden the work experience of interns and employees, and thus enable them to discover their intrinsic motivation. Such efforts can help increase employee confidence with regard to their careers, and so encourage them to work harder and perform better [86-88].

Furthermore, since hospitality education aims to prepare students for their future careers, hospitality management departments and instructors should aim to improve the curricula they offer by reviewing related studies and consulting with practitioners [89-91]. If students feel that they have obtained career-relevant information as part of their studies and internships, and thus have the abilities required to perform well, they will feel more intrinsically motivated and satisfied the focal course and major, and so will have more confidence with regard to the hospitality industry and greater willingness to pursue this as a career. Most important of all, by such efforts students can expect to have better learning outcomes and also be better trained for their intended careers, thus providing valuable human resources to the hospitality industry $[92,93]$.

\subsection{Limitations and Suggestions Future Research}

This study has the following limitations. The first limitation is that the results of this research could have been influenced by common method variance (CMV), as the students self-reported their perceptions of career decision-making self-efficacy, internship satisfaction, career commitment, intrinsic motivation, and intention to stay in the hospitality industry [94]. Future research could consider using different empirical approaches, such as obtaining data on employment rates or actual occupation status in the hospitality industry, to better understand the influences and consequences of career decision-making self-efficacy.

Another limitation is the fact that this was a cross-sectional study, which thus ignored the causality and reverse causality of the research variables. For example, students with different degrees of confidence about their personal abilities with regard to making career decisions might reveal their intention to stay in the industry differently [13-15]. In practice, students with high career decision-making self-efficacy could have more willingness to remain in the hospitality industry, while those with high intention to stay in the hospitality industry might have greater career decision-making self-efficacy. We thus suggest that future studies adopt a longitudinal approach or different models to investigate the causality and dynamic relationships among these constructs [95].

Finally, the research design used in this work ignored the individuals' relationships with their leaders and coworkers, and these vertical and horizontal relationships could also be important factors influencing an individual's intention to stay in the hospitality industry. Accordingly, future researchers are encouraged to consider applying leader-member exchange theory [96] and team-member exchange theory [97] to the model proposed in order to obtain a broader perspective with regard to the focal issues. 


\subsection{Conclusions}

Overall, this study expands the literature on Bandura's [11] social cognitive theory by emphasizing the effects of career decision-making self-efficacy on students' intention to stay in the hospitality industry after they have taken part in an internship. The results reveal that students with greater decision-making self-efficacy with regard to their careers are likely to feel greater internship satisfaction and career commitment, and that this can ultimately enhance their willingness to stay in the hospitality industry.

Funding: This research was funded by the major research plan of the Ministry of Science and Technology (MOST) of Taiwan (Grant No. MOST 109-2511-H-020-002-MY3).

Institutional Review Board Statement: Not applicable.

Informed Consent Statement: Not applicable.

Data Availability Statement: Data available on request due to privacy.

Conflicts of Interest: The authors declare no conflict of interest.

\section{References}

1. Collins, A.B. Gateway to the real world, industrial training: Dilemmas and problems. Tour. Manag. 2002, 23, 93-96. [CrossRef]

2. Hong, J.-C.; Zhang, H.-L.; Ye, J.-H.; Ye, J.-N. The effects of academic self-efficacy on vocational students behavioral engagement at school and at firm internships: A model of engagement-value of achievement motivation. Educ. Sci. 2021, 11, 387. [CrossRef]

3. Chen, T.-L.; Shen, C.-C. Today's intern, tomorrow's practitioner?-The influence of internship programmes on students' career development in the hospitality industry. J. Hosp. Leis. Sport Tour. Educ. 2012, 11, 29-40. [CrossRef]

4. Zopiatis, A.; Papadopoulos, C.; Theofanous, Y. A systematic review of literature on hospitality internships. J. Hosp. Leis. Sport Tour. Educ. 2021, 28, 100309. [CrossRef]

5. Mensah, C.; Appietu, M.E.; Asimah, V.K. Work-based social support and hospitality internship satisfaction. J. Hosp. Leis. Sport Tour. Educ. 2020, 27, 100242. [CrossRef]

6. Bandura, A. Self-efficacy: Toward a unifying theory of behavioral change. Psychol. Rev. 1977, 84, 191-215. [CrossRef] [PubMed]

7. Bandura, A.; Cervone, D. Self-evaluative and self-efficacy mechanisms governing the motivational effects of goal systems. J. Pers. Soc. Psychol. 1983, 45, 1017-1028. [CrossRef]

8. Hanham, J.; Lee, C.B.; Teo, T. The influence of technology acceptance, academic self-efficacy, and gender on academic achievement through online tutoring. Comput. Educ. 2021, 172, 104252. [CrossRef]

9. Malureanu, A.; Panisoara, G.; Lazar, I. The relationship between self-confidence, self-efficacy, grit, usefulness, and ease of use of eLearning platforms in corporate training during the Covid-19 pandemic. Sustainability 2021, 13, 6633. [CrossRef]

10. Hussain, I.; Nazir, M.; Hashmi, S.; Shaheen, I.; Akram, S.; Waseem, M.; Arshad, A. Linking green and sustainable entrepreneurial intentions and social networking sites; the mediating role of self-efficacy and risk propensity. Sustainability 2021, 13, 7050. [CrossRef]

11. Bandura, A. The self system in reciprocal determinism. Am. Psychol. 1978, 33, 344-358. [CrossRef]

12. Betz, N.E.; Klein, K.L.; Taylor, K.M. Evaluation of a short form of the career decision-making self-efficacy scale. J. Career Assess. 1996, 4, 47-57. [CrossRef]

13. Taylor, K.M.; Popma, J. An examination of the relationships among career decision-making self-efficacy, career salience, locus of control, and vocational indecision. J. Vocat. Behav. 1990, 37, 17-31. [CrossRef]

14. Solberg, V.S.; Good, G.E.; Fischer, A.R.; Brown, S.D.; Al, E. Career decision-making and career search activities: Relative effects of career search self-efficacy and human agency. J. Couns. Psychol. 1995, 42, 448-455. [CrossRef]

15. Betz, N.E.; Luzzo, D.A. Career assessment and the career decision-making self-efficacy scale. J. Career Assess. 1996, 4, 413-428. [CrossRef]

16. Chen, S.; Chen, H.; Ling, H.; Gu, X. How do students become good workers? Investigating the impact of gender and school on the relationship between career decision-making self-efficacy and career exploration. Sustainability 2021, 13, 7876. [CrossRef]

17. Miller, M.J.; Roy, K.S.; Brown, S.D.; Thomas, J.; McDaniel, C. A confirmatory test of the factor structure of the short form of the career decision self-efficacy scale. J. Career Assess. 2009, 17, 507-519. [CrossRef]

18. Porter, L.W.; Steers, R.M.; Mowday, R.T.; Boulian, P.V. Organizational commitment, job satisfaction, and turnover among psychiatric technicians. J. Appl. Psychol. 1974, 59, 603-609. [CrossRef]

19. Wu, C.-H.; Griffin, M.A. Longitudinal relationships between core self-evaluations and job satisfaction. J. Appl. Psychol. 2012, 97, 331-342. [CrossRef] [PubMed]

20. Blau, G.J. Further exploring the meaning and measurement of career commitment. J. Vocat. Behav. 1988, 32, 284-297. [CrossRef]

21. Jadidian, A.; Duffy, R.D. Work volition, career decision self-efficacy, and academic satisfaction. J. Career Assess. 2011, 20, 154-165. [CrossRef] 
22. Fuller, J.B.; Hester, K.; Dickson, P.; Allison, B.J.; Birdseye, M. A closer look at select cognitive precursors to organizational turnover: What has been missed and why. Psychol. Rep. 1996, 78, 1331-1352. [CrossRef]

23. Chung, Y.B. Career decision-making self-efficacy and career commitment: Gender and ethnic differences among college students. J. Career Dev. 2002, 28, 277-284. [CrossRef]

24. Baruch, Y.; Winkelmann-Gleed, A. Multiple commitments: A conceptual framework and empirical investigation in a community health service trust. Br. J. Manag. 2002, 13, 337-357. [CrossRef]

25. Lee, K.; Carswell, J.J.; Allen, N. A meta-analytic review of occupational commitment: Relations with person- and work-related variables. J. Appl. Psychol. 2000, 85, 799-811. [CrossRef] [PubMed]

26. Amabile, T.M. The social psychology of creativity: A componential conceptualization. J. Pers. Soc. Psychol. 1983, 45, 357-376. [CrossRef]

27. Ryan, R.M.; Deci, E.L. Self-determination theory and the facilitation of intrinsic motivation, social development, and well-being. Am. Psychol. 2000, 55, 68-78. [CrossRef] [PubMed]

28. Venkatesh, V. Determinants of perceived ease of use: Integrating control, intrinsic motivation, and emotion into the technology acceptance model. Inf. Syst. Res. 2000, 11, 342-365. [CrossRef]

29. Deci, E.L. Effects of externally mediated rewards on intrinsic motivation. J. Pers. Soc. Psychol. 1971, 18, 105-115. [CrossRef]

30. Conti, R.; Coon, H.; Amabile, T.M. Evidence to support the componential model of creativity: Secondary analyses of three studies. Creat. Res. J. 1996, 9, 385-389. [CrossRef]

31. Duffy, R.D.; Blustein, D.L. The relationship between spirituality, religiousness, and career adaptability. J. Vocat. Behav. 2005, 67, 429-440. [CrossRef]

32. Steele-Johnson, D.; Beauregard, R.S.; Hoover, P.B.; Schmidt, A.M. Goal orientation and task demand effects on motivation, affect, and performance. J. Appl. Psychol. 2000, 85, 724-738. [CrossRef]

33. Lai, L.; Kapstad, J.C. Perceived competence mobilization: An explorative study of predictors and impact on turnover intentions. Int. J. Hum. Resour. Manag. 2009, 20, 1985-1998. [CrossRef]

34. Siu, G.; Cheung, C.; Law, C.H.R. Developing a conceptual framework for measuring future career intention of hotel interns. J. Teach. Travel Tour. 2012, 12, 188-215. [CrossRef]

35. Kim, H.-B.; Park, E.J. The role of social experience in undergraduates' career perceptions through internships. J. Hosp. Leis. Sport Tour. Educ. 2013, 12, 70-78. [CrossRef]

36. Chi, C.G.; Gursoy, D. How to help your graduates secure better jobs? An industry perspective. Int. J. Contemp. Hosp. Manag. 2009, 21, 308-322. [CrossRef]

37. Cho, M. Student perspectives on the quality of hotel management internships. J. Teach. Travel Tour. 2006, 6, 61-76. [CrossRef]

38. Choudhury, N.; McIntosh, A. Retaining students as employees: Owner operated small hospitality businesses in a university town in New Zealand. Int. J. Hosp. Manag. 2013, 32, 261-269. [CrossRef]

39. Hsu, M.-S. A study of internship attitude, subjective norm, perceived behavioral control, and career planning of hospitality vocational college students. J. Hosp. Leis. Sport Tour. Educ. 2012, 11, 5-11. [CrossRef]

40. Kwok, L.; Adams, C.R.; Feng, D. A comparison of graduating seniors who receive job offers and those who do not according to hospitality recruiters' selection criteria. Int. J. Hosp. Manag. 2012, 31, 500-510. [CrossRef]

41. Bandura, A. The explanatory and predictive scope of self-efficacy theory. J. Soc. Clin. Psychol. 1986, 4, 359-373. [CrossRef]

42. Betz, N.E.; Hammond, M.; Multon, K.D. Reliability and validity of five-level response continua for the career decision self-efficacy scale. J. Career Assess. 2005, 13, 131-149. [CrossRef]

43. Buyukgoze-Kavas, A. A psychometric evaluation of the career decision self-efficacy scale-short form with Turkish University students. J. Career Assess. 2014, 22, 386-397. [CrossRef]

44. Presti, A.L.; Pace, F.; Mondo, M.; Nota, L.; Casarubia, P.; Ferrari, L.; Betz, N.E. An examination of the structure of the career decision self-efficacy scale (short form) among Italian high school students. J. Career Assess. 2013, 21, 337-347. [CrossRef]

45. Bandura, A. Self-Efficacy: The Exercise of Control; W.H. Freeman: New York, NY, USA, 1997; p. 604.

46. Bandura, A. Self-efficacy determinants of anticipated fears and calamities. J. Pers. Soc. Psychol. 1983, 45, 464-469. [CrossRef]

47. Wang, C.-J.; Tsai, H.-T.; Tsai, M.-T. Linking transformational leadership and employee creativity in the hospitality industry: The influences of creative role identity, creative self-efficacy, and job complexity. Tour. Manag. 2014, 40, 79-89. [CrossRef]

48. Peterson, S. Career decision-making self-efficacy, integration, and the likelihood of managerial retention in governmental agencies. Hum. Resour. Dev. Q. 2009, 20, 451-475. [CrossRef]

49. Adachi, T. Career development by university students: Social cognitive career theory. Jpn. J. Educ. Psychol. 2001, 49, 326-336. [CrossRef]

50. Jantzer, A.M.; Stalides, D.J.; Rottinghaus, P.J. An exploration of social cognitive mechanisms, gender, and vocational identity among eighth graders. J. Career Dev. 2009, 36, 114-138. [CrossRef]

51. Tett, R.P.; Meyer, J.P. Job satisfaction, organizational commitment, turnover intention, and turnover: Path analyses based on meta-analytic findings. Pers. Psychol. 2006, 46, 259-293. [CrossRef]

52. Komarraju, M.; Swanson, J.; Nadler, D. Increased career self-efficacy predicts college students? Motivation, and course and major satisfaction. J. Career Assess. 2013, 22, 420-432. [CrossRef]

53. Choi, K.; Kim, D.-Y. A cross cultural study of antecedents on career preparation behavior: Learning motivation, academic achievement, and career decision self-efficacy. J. Hosp. Leis. Sport Tour. Educ. 2013, 13, 19-32. [CrossRef] 
54. Song, Z.; Chon, K. General self-efficacy's effect on career choice goals via. vocational interests and person-job fit: A mediation model. Int. J. Hosp. Manag. 2012, 31, 798-808. [CrossRef]

55. Dahling, J.J.; Thompson, M.N. Detrimental relations of maximization with academic and career attitudes. J. Career Assess. 2013, 21, 278-294. [CrossRef]

56. Wright, S.L.; Perrone, K.M. An examination of the role of attachment and efficacy in life satisfaction. Couns. Psychol. 2010, 38, 796-823. [CrossRef]

57. Chiang, C.-F.; Back, K.-J.; Canter, D.D. The impact of employee training on job satisfaction and intention to stay in the hotel industry. J. Hum. Resour. Hosp. Tour. 2005, 4, 99-118. [CrossRef]

58. Vandenberghe, C.; Ok, A.B. Career commitment, proactive personality, and work outcomes: A cross-lagged study. Career Dev. Int 2013, 18, 652-672. [CrossRef]

59. Blau, G.J. The measurement and prediction of career commitment. J. Occup. Psychol. 1985, 58, 277-288. [CrossRef]

60. Jin, L.; Watkins, D.; Yuen, M. Personality, career decision self-efficacy and commitment to the career choices process among Chinese graduate students. J. Vocat. Behav. 2009, 74, 47-52. [CrossRef]

61. Chemers, M.M.; Zurbriggen, E.L.; Syed, M.; Goza, B.K.; Bearman, S. The role of efficacy and identity in science career commitment among underrepresented minority students. J. Soc. Issues 2011, 67, 469-491. [CrossRef]

62. Kim, Y.-G.; Kim, S.; Yoo, J.-L. Travel agency employees' career commitment and turnover intention during the recent global economic crisis. Serv. Ind. J. 2012, 32, 1247-1264. [CrossRef]

63. Ryan, R.M.; Deci, E. Intrinsic and extrinsic motivations: Classic definitions and new directions. Contemp. Educ. Psychol. 2000, 25, 54-67. [CrossRef]

64. Wang, C.-J. Does leader-member exchange enhance performance in the hospitality industry? Int. J. Contemp. Hosp. Manag. 2016, 28, 969-987. [CrossRef]

65. Brislin, R.W. Back-translation for cross-cultural research. J. Cross-Cult. Psychol. 1970, 1, 185-216. [CrossRef]

66. Lam, T.; Ching, L. An exploratory study of an internship program: The case of Hong Kong students. Int. J. Hosp. Manag. 2007, 26, 336-351. [CrossRef]

67. Hambleton, R.K. The next generation of the ITC test translation and adaptation guidelines. Eur. J. Psychol. Assess. 2001, 17, 164-172. [CrossRef]

68. Wong, S.; Pang, L. Motivators to creativity in the hotel industry-Perspectives of managers and supervisors. Tour. Manag. 2003, 24, 551-559. [CrossRef]

69. Bowling, N.A.; Hammond, G.D. A meta-analytic examination of the construct validity of the Michigan organizational assessment questionnaire job satisfaction subscale. J. Vocat. Behav. 2008, 73, 63-77. [CrossRef]

70. Shalley, C.E.; Gilson, L.; Blum, T.C. Interactive effects of growth need strength, work context, and job complexity on self-reported creative performance. Acad. Manag. J. 2009, 52, 489-505. [CrossRef]

71. Zopiatis, A.; Theocharous, A.L. Revisiting hospitality internship practices: A holistic investigation. J. Hosp. Leis. Sport Tour. Educ. 2013, 13, 33-46. [CrossRef]

72. Bagozzi, R.P.; Yi, Y. On the use of structural equation models in experimental designs. J. Mark. Res. 1989, 26, 271. [CrossRef]

73. Fornell, C.; Larcker, D.F. Evaluating structural equation models with unobservable variables and measurement error. J. Mark. Res. 1981, 18, 39-50. [CrossRef]

74. Anderson, J.C.; Gerbing, D.W. Structural equation modeling in practice-A review and recommended two step approach. Psychol. Bull. 1988, 103, 411-423. [CrossRef]

75. Novikova, S.I.; Richman, D.M.; Supekar, K.; Barnard-Brak, L.; Hall, D. Chapter three-NDAR: A model federal system for secondary analysis in developmental disabilities research. In International Review of Research in Developmental Disabilities; Urbano, R.C., Ed.; Academic Press: Cambridge, MA, USA, 2013; Volume 45, pp. 123-153.

76. Arbuckle, J.L. IBM SPSS Amos 22 User's Guide; IBM Corporation: Armonk, NY, USA, 2013.

77. Barrett, P. Structural equation modelling: Adjudging model fit. Pers. Individ. Differ. 2007, 42, 815-824. [CrossRef]

78. Baron, R.M.; Kenny, D.A. The moderator mediator variable distinction in social psychological-research-Conceptual, strategic, and statistical considerations. J. Pers. Soc. Psychol. 1986, 51, 1173-1182. [CrossRef]

79. Sobel, M.E. Asymptotic confidence intervals for indirect effects in structural equation models. In Sociological Methodology; Leinhardt, S., Ed.; American Sociological Association: Washington, DC, USA, 1982; pp. 290-312.

80. Taylor, A.B.; MacKinnon, D.P.; Tein, J.-Y. Tests of the three-path mediated effect. Organ. Res. Methods 2007, 11, 241-269. [CrossRef]

81. Preacher, K.J.; Hayes, A.F. Asymptotic and resampling strategies for assessing and comparing indirect effects in multiple mediator models. Behav. Res. Methods 2008, 40, 879-891. [CrossRef]

82. Putit, N.; Atlas, R.; Hanan, H.; Ramie, K.; Lua, L.; Abd Rahim, R. Career decision making among hospitality undergraduates in UiTM Shah Alam and Puncak Alam. In Current Issues in Hospitality and Tourism Research and Innovations; CRC Press: Boca Raton, FL, USA, 2012; pp. 25-29.

83. Zhong, Y.Y.; Hertzman, J. Identifying factors that influence hospitality students' willingness to work with older employees. J. Hosp. Tour. Educ. 2014, 26, 21-28. [CrossRef]

84. Úbeda-García, M.; Marco-Lajara, B.; Sabater-Sempere, V.; García-Lillo, F. Training policy and organisational performance in the Spanish hotel industry. Int. J. Hum. Resour. Manag. 2013, 24, 2851-2875. [CrossRef] 
85. Martinez-Ros, E.; Orfila-Sintes, F. Training plans, manager's characteristics and innovation in the accommodation industry. Int. J. Hosp. Manag. 2012, 31, 686-694. [CrossRef]

86. Aragon-Correa, J.A.; Martin-Tapia, I.; de la Torre-Ruiz, J.M. Sustainability issues and hospitality and tourism firms' strategies. Int. J. Contemp. Hosp. Manag. 2015, 27, 498-522. [CrossRef]

87. Wu, C.-M.; Chen, T.-J. Psychological contract fulfillment in the hotel workplace: Empowering leadership, knowledge exchange, and service performance. Int. J. Hosp. Manag. 2015, 48, 27-38. [CrossRef]

88. Wong, T.; Wickham, M. An examination of Marriott's entry into the Chinese hospitality industry: A brand equity perspective. Tour. Manag. 2015, 48, 439-454. [CrossRef]

89. Dressier, S.; Cedercreutz, K.; Pacheco, A. Strengthening curriculum through student learning outcome assessment in experiential learning. J. Hosp. Tour. Educ. 2011, 23, 41-47. [CrossRef]

90. Barber, N.; Deale, C.; Goodman, R. Environmental sustainability in the hospitality management curriculum: Perspectives from three groups of stakeholders. J. Hosp. Tour. Educ. 2011, 23, 6-17. [CrossRef]

91. Lefever, M.M.; Withiam, G. Curriculum review: How industry views hospitality education. Cornell Hotel Restaur. Admin. Q. 1998, 39, 70-78. [CrossRef]

92. Talib, J.A.; Salleh, A.; Amat, S.; Ghavifekr, S.; Ariff, A.M. Effect of career education module on career development of community college students. Int. J. Educ. Vocat. Guid. 2014, 15, 37-55. [CrossRef]

93. Sobaih, A.E.; Jones, E. Bridging the hospitality and tourism university-industry research gap in developing countries: The case of Egypt. Tour. Hosp. Res. 2015, 15, 161-177. [CrossRef]

94. Podsakoff, P.M.; MacKenzie, S.B.; Lee, J.Y.; Podsakoff, N.P. Common method biases in behavioral research: A critical review of the literature and recommended remedies. J. Appl. Psychol. 2003, 88, 879-903. [CrossRef]

95. Parker, S.K. Enhancing role breadth self-efficacy: The roles of job enrichment and other organizational interventions. J. Appl. Psychol. 1998, 83, 835-852. [CrossRef]

96. Graen, G.; Novak, M.A.; Sommerkamp, P. The effects of leader-Member exchange and job design on productivity and satisfaction: Testing a dual attachment model. Organ. Behav. Hum. Perform. 1982, 30, 109-131. [CrossRef]

97. Seers, A. Team-member exchange quality: A new construct for role-making research. Organ. Behav. Hum. Decis. Process. 1989, 43, 118-135. [CrossRef] 